DOI: https://doi.org/10.31392/NPU-nc.series9.2018.17.01

UDC: $81 ’ 373.612 .2: 165.194$

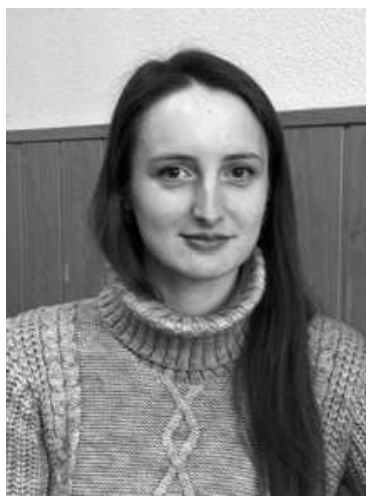

National Pedagogical Dragomanov University, Kyiv, Ukraine

\title{
COGNITIVE MECHANISM OF ANALOGY AND ITS ROLE IN PROCESSES OF PRIMARY METAPHOR CREATION
}

\section{Bibliographic Description:}

Borodiichuk, N. V. (2018). Cognitive Mechanism of Analogy and its Role in Processes of Primary Metaphor Creation. Scientific Journal of National Pedagogical Dragomanov University. Series 9. Current Trends in Language Development. K. 17. 5-18. DOI: https://doi.org/10.31392/NPU-nc.series9.2018.17.01

\begin{abstract}
The article deals with the problem of the cognitive nature of metaphor formed in the medium of mythological consciousness of the primitive human. It is supposed that such the main features of the mythological thinking as sensory concreteness and inability to form abstract notions caused the nature of the primary metaphor which was formed through the cognitive mechanism of analogy the surrounding objects and phenomena, and the inner mental states of the human - this metaphor was not linguistic, but concrete and sensory. It is ascertained that the direction of metaphorization in the primitive consciousness was inverted to modern one, because the modern people mind uses more intelligible concrete concepts to express abstract concepts, but the primitive humans conceiving themselves as a part of the nature and understanding their inner world as the outer one projected their inner states, which are comprehended as abstract now, onto the natural phenomena, which can be perceived through the organs of sense. It is argued that formation of critical abstract thinking is related with the development of the human cognitive abilities, what caused the metaphorization veer and also the transition from the mythological mind to linguistic one. It is analyzed three approaches to solving the problem of the relation between language and myth where an important argument was the metaphoricity both of thinking and language: 1) the linguistic theory of myth by M. Müller according to which the loss initial sense of the linguistic metaphor generated myth; 2) the theory of myth based not on the linguistic metaphor, but on the concrete sensory analogy of the real objects and human perceptions (E. Tylor, A. Potebnya); 3) Neo-Kantian theory by E. Cassirer which postulates the simultaneous development of language and myth which have the common sources. It is proved that metaphoricity is inherent in the human mind of every historical period, because the linguistic metaphor is based on the cognitive one, that is the latter makes it possible to comprehend the world and ourselves in this world and express the obtained knowledge by means of language. At the same time, metaphoricity and abstractness of thinking are harmonious processes which provides the productive cognizing of the world and the creative working its results out through the fixation of them in the linguistic forms.
\end{abstract}

Keywords: primary metaphor, mythological consciousness, cognitive mechanism of analogy, linguistic metaphor, cognitive metaphor. 


\section{Introduction.}

Metaphor as the main object of metaphorology (Yu. V. Kravtsova) at the current stage of its development is being studied actively with the tide of cognitive linguistics, which representatives (G. Lakoff, M. Johnson, Z. Kövecses, A. Cienki, B. Rudzka-Ostyn, M. Turner, G. Fauconnier et al.) claim that the metaphorical "linguistic expressions (i.e., ways of talking) make explicit, or are manifestations of, the conceptual metaphors (i.e., ways of thinking)" (Kövecses 2010: 7), as well the conceptual metaphor "can be seen as a key instrument not only in producing new words and expressions but also in organizing human thought" (Kövecses 2010: xii). Due to the fact that the human psyche and therefore the ways of human thinking have undergone phylogenetic changes since the time of primitive society when primitive consciousness began comprehending the world and itself as a part of this world and then expressing the human ideas about the objective reality through the language forms (A. Losev, G. Vico, E. Cassirer et al.), we can suppose that the mechanisms of metaphor creation have also undergone transformation.

Various approaches to conceptual metaphor (the general theory of metaphor by G. Lakoff and M. Johnson, the theory of conceptual integration by G. Fauconnier and M. Turner, cognitive poetics by R. Tsur, M. Freeman, Z. Kövecses et al.) agree on that "the locus of metaphor is not in language at all, but in the way we conceptualize one mental domain in terms of another" (Lakoff 1993: 203), moreover "conceptual metaphors typically employ a more abstract concept as target and a more concrete or physical concept as their source", because "if we want to fully understand an abstract concept, we are better off using another concept that is more concrete, physical, or tangible than the abstract target concept for this purpose. Our experiences with the physical world serve as a natural and logical foundation for the comprehension of more abstract domains" (Kövecses 2010: 7), thereby, "many elements of target concepts come from source domains and are not preexisting" (Kövecses 2010: 9).

This phenomenon is explained with the idea of embodied mind under which "an embodied concept is a neural structure that is actually part of, or makes use of, the sensorimotor system of our brains. Much of conceptual inference is, therefore, sensorimotor inference" (Lakoff, Johnson 1999: 20), that is why people conceptualize the world and themselves through the embodied experience of the world and themselves in this world. Such "abstract ideas, like love, life, and the pursuit of happiness, are understood through the conceptual projection of physical experience. In other words, we cannot think abstractly without thinking metaphorically" (Freeman 2000: 266). Thus, according to "the embodiment hypothesis, metaphors may serve as conduits that link sensorimotor experience with abstract concepts" (Holyoak, Stamenkovic 2018: 656).

Although there are some points of view arguing that "abstract terms are not metaphorical, nor is metaphor comprehension embodied" (Kompa 2017: 206), we are positive of that metaphoricity and abstractedness of human mind are closely related and determined by physical experience since abstract concepts are comprehended and expressed through the means of language, first and foremost, by virtue of the conceptual metaphor, which is a product of abstract thinking and created on the base of specific mechanisms.

Just as the creation of metaphor is a cognitive process, on the one hand, and the linguistic one, on the other hand, so it provides the opportunity to reconstruct the mechanisms of the primitive human thinking as well as of current one. The aim of the article is revealing of cognitive mechanisms of the primary metaphor creation.

\section{Intuitive and Sensory Sphere of the Primary Metaphor Creation.}

Consciousness of the primitive human is defined (A. Losev, G. Vico, E. Cassirer, J. Frazer et al.) as mythological which is characterized by incorporated, prelogical thinking, 
that is the primitive human equated subject and object of perception, natural and cultural phenomena, did not distinguish part-to-whole relations and also causal links (the next event could be the reason for the previous one, simultaneous events could have some causal link), that is why "the world view of the prelogical mind is that everything could hold anything", there is hence prerational, sensory character of the mythological consciousness, that is abstractions undergo sensory objectification (Timofeev, Petrov 2010: 146-147).

According to A. Losev, the basic nature of mythological mind is that if humans do not separate themselves from nature and conceive surroundings as sensory as themselves, they do not oppose their thought to surroundings and every abstract thought which reflects reality is the reality itself for mythological mind with all its sensory properties as alive beings or inanimate things (Losev 1964: 458). It follows that primitive consciousness did not discern abstract from material, that is why did not aspire to express abstract concepts using more easily understood concrete concepts, because abstract was conceived as sensory. It gives an explanation to cognitive nature of the primary metaphor which is based on identity of an object and thought about it; if the thought about some object or phenomenon arises, this object or phenomenon really exist for primitive human.

Corroboration of these theses can be found in the works of J. Ortega y Gasset who claims that mind unable to abstract thoughts would not distinguish metaphor as a finished result from metaphorical thought as a process (Ortega y Gasset 1990: 69). The primitive human mind was exactly like that because that notions which modern people understand as metaphorical were understood as absolutely real by humans of that evolutionary stage.

Researcher supposes that metaphor needs realization of its duality since we deliberately misuse a name (Ortega y Gasset 1990: 71), that is why metaphor functions not only to give a name or explicate unknown phenomena, but also to comprehend them. In his opinion, metaphor "is needed not only to make accessible our thought for other people by virtue of the obtained name, but to make an object accessible for our mind. Metaphor is not only the expressive means, metaphor is also the important means of thinking" (Ortega y Gasset 1990: 71), "through which we manage to reach the remotest areas of our conceptual field. Objects close to us, which can be easily comprehended, make mind available to reach remote concepts" (Ortega y Gasset 1990: 72). As we can see, J. Ortega y Gasset endeavours to explain the mechanisms of metaphor creation which are, indeed, cognitive.

Probably, the primitive humans thought in the same way to comprehend that notions which had arisen on the periphery of their consciousness, but it already was the way to comprehend the abstract concepts since at first human mind tried to seize the concrete things which surrounded the human and to conceptualize them - these concepts form the oldest layer of human consciousness. That is why metaphor becomes increasingly necessary because of that the human mind moves away from concrete things of daily life (Ortega $y$ Gasset 1990: 75).

Modern people create metaphor deliberately to designate new notions which are difficult to describe by available language means or use already formed metaphorical models to name notions comprehended long ago, at the same time they can modify verbal forms which express these basic models formed when primitive humans began feeling the necessity to reflect not only the objective world, but also abstract one, because they were overfull with various impression and emotions. That means the primary metaphors were creating not so much consciously as intuitive and sensory, through the cognitive mechanism of various analogy with the world of objective notions. 


\section{Mythological Nature of Cognitive Mechanism of Analogy as the Basis of Primary Metaphor Creation.}

Abstractness as a cognitive ability of the primitive human mind should be understood conditionally because of the peculiarities of the primitive psyche. According to C. Jung, "myths, first and foremost, are the mental phenomena expressing the deep essence of the soul", because the primitive humans were not "inclined to explain objectively the most obvious things", that is why they aspired "to adapt all external experience to the mental events" (Jung 1991 URL: http://gtmarket.ru/laboratory/basis/4229/4232). That is myth arises when the existence of unconscious as a part of psyche has not realized by the primitive humans yet and they projected the state of their unconscious onto the surroundings; thus the inner world of the primitive human (which was understood as the outer one) is expressed through mythology: "mythologized natural processes are ... symbolical expressions of the inner and unconscious drama of the soul. It is perceived by human mind through projections, that means it is reflected in the mirror of natural events" (Jung 1991 URL: http://gtmarket.ru/laboratory/basis/4229/4232).

These thoughts of C. Jung afford ground for claiming that analogy as a cognitive mechanism of the primeval metaphor is like inverted to the modern one; if nowadays the source domain of the cognitive metaphor contains more concrete concepts some elements of which are mapped onto elements of the more abstract concepts of the target domain, then the primitive humans projected the state of their soul onto the surroundings, however, without understanding of that fact - it explains anthropomorphism and animism of myths. Human separation from nature and then from the tribal society, realization of the selfhood allegedly inverted the cognitive process of metaphorization, however, probably did not change already formed cognitive models of metaphors which were created on the basis of humans' ability to express their inner world through the natural phenomena.

And since the peculiar property of the primitive culture is syncretism, that is the union of different embryonic forms of reality comprehension contained in mythology (Timofeev, Petrov 2010: 147-148), the researchers resort to comparison between the mythological consciousness and other its forms (religious, scientific, philosophic, artistic), in particular to comparison of the cognitive mechanisms of metaphorization as the processes inherent in all these forms.

In this respect J. Ortega y Gasset mentions a poetical metaphor as "a total identity of two things" (Ortega y Gasset 1990: 73-74); this definition is similar to the principles of the primitive magic consciousness (J. Frazer, E. Cassirer): 1) principle "a part instead of the whole" which means a wizard believes that exerting influence on the part of some object he can have an influence on the whole object (ex., some magic actions with somebody's hair will have effect on this person completely); 2) principle of analogy which means that similar objects are understood as identical, that is the wizard is positive of doing some action will provoke the same natural phenomenon (ex., watering the ground will cause the rain) (Cassirer 1990: 38; Frazer 1986: 19-20).

However, these principles do not mean that the primitive human did not distinguish objects with similar features, because categorization of surrounding objects was necessary to survive (Lakoff, Johnson 1999: 17-18). Above mentioned principles obviously indicate that the primitive human comprehended some relations between the objects or phenomena, although was not able (did not have cognitive ability) to make right conclusions about these relations. Thus J. Frazer notices that conceiving themselves united with nature the primitive humans deemed if everything is connected and interdependent in nature, then some their actions will have corresponding results in nature, because they were not able to distinguish the objective causal link between some phenomena from the subjective associations which 
were present only in their mind (Frazer 1986: 19-20), that is why magic is naive application of the simplest intellectual operations which are: association of ideas by similarity and association of ideas by contiguity (Frazer 1986: 58). These statements can be seen as the corroboration of supposition that the imaginary world was quite real for the primitive humans, feeling of analogy between the perception of reality through the sense organs and inaccessible for them abstract phenomena leaded to equation of these facts resulting as the primary metaphor.

G. Vico's thoughts about metaphorical nature of myth, poetry of the primitive human mind and its expression in the language attract particular attention. The philosopher understands history as a cyclical process which laws are analogical to the laws of a biological organism's development, that is why mythological epoch of human development corresponds to childhood period of an individual since the children's psyche is characterized by emotionality, fertile imagination, sensory concreteness, transfer of their qualities onto the surroundings etc. and these peculiarities are quite correspondent to the features of mythological mind. Children use their imagination to compensate for the lack of the objective knowledge; according to G. Vico, mythology forms in this manner: "the first people like children of the human race were unable to form intelligible generic notions, that is why they were forced to create poetic characters, that is fantastic genera or universals, to reduce to them as to some Patterns or ideal portraits all individual species similar to their genus" (Vico 1994: 87). Thus G. Vico claims that myth is a phenomenon inherent in the childhood of the human race, that is primitive society, however it is not fiction or ignorance but peculiar reality refraction through the lens of mythological consciousness. Modern people, according to G. Vico, are bereft of those abilities of the primitive consciousness which were the basis and the reason of mythogenesis: "[...] the nature of the human mind is already too far from those feelings because of numerous abstractness..., nowadays the nature prevented access to irrepressible Imagination of the first people whose consciousness was bereft of abstractness [...], because they were absolutely immersed into sensations...; now we even cannot fancy how the first people, who set up the Pagan culture, thought" (Vico 1994: 134).

G. Vico claims that the primitive human mind was metaphorical and therefore poetical: "The first Poets imparted to the objects the nature of animated substances which owned only what they themselves were capable of, that is feeling and passion; in such a manner the first Poets changed the objects into the Myths and every metaphor became a little myth" (Vico 1994: 146). The philosopher writes that "all the languages have expressions which are transferred onto inanimate beings from the human body and its parts, from the human feelings and passions" (Vico 1994: 149).

The transfer of the human passions onto the natural phenomena is quite correlating with already mentioned thoughts of C. Jung about the mythological mind, because direction of metaphorization was not from the concrete to the abstract, but vice versa, although the abstract was conceived as concrete and sensory. Thus, according to G. Vico, "all the tropes [...] were the expressive ways of the first Poetic Nations and, by nature, they had literal meaning. However, development of the human mind resulted into arising of language, and the words having denoted the abstract forms and generic notions which had linked parts with their whole became figurative or metaphorical according to the expressive ways of the primitive humans" (Vico 1994: 149). Hence the philosopher's statement about the initial arising of the poetic language and the further development of the prose language.

However, modern artistic mind and primitive mythological one are different by nature. According to E. Cassirer, in due course the tight relation between myth and language slackens, because "language does not belong to the field of myth, there is another force in it 
from its origins - it is the force of logos", that is why "during the development of language the word more and more becomes only a sign of concept"; that is the transformation of language into a tool of thinking by means of which the concepts and judgements are expressed is only possible in case of loss by it of "the direct experience", "the initial concrete conceptual and emotional content" (Cassirer 1990: 41). Herewith the researcher notices when the word is used "with the purpose of the artistic expression", it "not only saves its initial descriptive force but also continually renovates it maintaining persistent palingenesis, emotional and spiritual dimensions", but this "new life" of the word is already "esthetically independent", "not related with myth", because the word expressed in poetry "is neither the mythological world of gods and demons nor the logical truth of the abstract denotations and relations. The world of poetry is [...] the world of illusion and fantasy" (Cassirer 1990: 4142). Hence the poetical creative work of a person who is able to abstract thinking provides for the deliberate fantasy formation and using of metaphors which are not already concrete and sensory as they were in the time of mythogenesis, but they still function as the means of feelings' expression.

Appurtenance of the myth to the sphere of poetry is also noticed in the works of A. Potebnya who claims that myth "is constituted with an image and meaning which relation is not needed to be proved as it is done in science, because it is directly persuasive, accepted at face value", that is why myth is a result of an act of consciousness, but it differs from the latter by the fact that it runs unconsciously (Potebnya 1989: 259). According to A. Potebnya, the difference between the myth and the later poetry consists in "the attitude of consciousness to the elements of both of them" since "the image and meaning of the myth are different, allegory of the image exists, but it is not realized by a subject, the image wholly (without getting dismembered) transfers to the meaning", then "the image of the later poetry is not more than the means of forming (realization) of the meaning, the means which get dismembered into its elements", so "the two parts of judgement (viz. image and meaning) are more similar by the mythological thinking, than by poetical one. Their differentiation leads from the myth to the poetry and then from the poetry to the prose and science" (Potebnya 1989: 259). As we can see, the artistic mind separated from mythological one when the human began understanding the difference between the sign and the signified: "The emergence of metaphor in the sense of heterogeneity of the image and meaning is a result of the myth's disappearance" (Potebnya 1989: 261), but in this case the metaphor lost its concrete sensuousness having become the means of conscious transfer of the features of the concrete concepts onto the abstract ones.

Thus, the primary metaphor inherent in mythological mind differs from the artistic metaphor by absence of the sensory concreteness in the latter, that is the mythological mind was not poetical in the modern sense, because poetry is just one of the properties of the mythological mind since the latter held the germs of all other forms of mind which afterwards separated, in particular the artistic one. Comparing the mythological fantasy with the artistic one A. Losev claims that "the mythological images were thought to be substantiated in the literal sense and were not the metaphor in the modern understanding whereas the artistic images are always understood just figuratively" (Losev 1964: 458). During the artwork the purposeful process of linguistic metaphorization or using of the linguistic forms reflecting knowledge formed through the cognitive metaphor take place consciously, and during the mythogenesis the cognitive mechanism of analogy comes about resulting as the metaphor creation.

Hereby "myth is a sensory belief rather than abstract" (Losev 1964: 457), but we should not oppose the mythological mind to the metaphorical thinking and understand the abstractness and metaphoricity of thinking as mutually exclusive. Metaphoricity is an 
integral part of the human mind of every historical period, it is impossible neither to comprehend surroundings and ourselves, nor to express the results of this comprehension through the language without it. The evolution of the human mind did not deprive the metaphor of the main its mechanism, which is the mechanism of analogy, but provided people with higher creative level of knowledge of the world through the coexistence of the metaphorical and abstract thinking.

\section{Research Directions of the Cognitive Mechanism of Analogy as a Way of the Primary Metaphor Creation.}

The problem of the cognitive nature of the primary metaphor was studied within the discussion about the primacy of language in relation to myth or, contrariwise, the primacy of myth in relation to language. There were three research directions which propounded the next ideas: 1) formation of language preceded the arising of mythology (linguistic theory of myth by M. Müller, A. Kuhn, F. Wendorff, H. Usener et al.); 2) myth is a prelinguistic phenomenon which gained linguistic narrative forms and then the language manifested mythogenic potential (E. Tylor, A. Potebnya); 3) myth and language are interdependent phenomena which cause the formation of each other (E. Cassirer, J. Herder, F. Schelling).

4.1. The Linguistic Theory of Myth arose in the middle of the XIX century and it was contiguous to the ideas of the comparative linguistics. According to this theory, myth is closely related with the language, because the latter is the most important factor of mythogenesis. It is focused on "the correlation between the semantics and metaphorical organization of the myth which discoordination ("obliteration" of the initial sense of the metaphors) was considered as the basis of mythogenesis" (Mozheyko 2003 URL: http://www.gumer.info/bogoslov_Buks/Philos/New_Dict/477.php). M. Müller, who is the founder of this theory, thought $\bar{m} y$ thology to be the sickness of language: "Mythology like the poison of the ancient world is, in fact, the sickness of language. Mythos means the word that had been a name or attribute, but had time to assume more real existence" (Müller 2009: 8). The researcher thought that mythology is the special speech, ancient envelope of the language, that is the nature of myth was inferred from the particularities of thoughts' objectification in the language (Naydysh 2010: 215).

Metaphoricity is the common feature of myth and language, but, according to M. Müller, the metaphorical thinking preceded the mythological one, because the primitive humans perceived the surrounding objects as themselves and not having enough words to designate elements of the outer world they used the same words to name their inner states and the outer objects; the primitive humans "embraced with the same expression material and abstract notions" (Müller 1887: 28). Myth was formed when the initial (literal) sense of metaphor was lost: "Eos was the name of the sunrise colors until it became a goddess" (Müller 2009: 8).

V. Naydysh treats the approach of the linguistic theory of myth in the following way: "the primitive mythology is inferred from the fact that the initial designation of the abstract notions through the concrete features of phenomena can be realized only through the metaphor. That is the primitive human thought only metaphorically, in other words, poetically. There is no mythology at this stage. But after a while when the initial sense of metaphor was lost the metaphors began to be used without a clear understanding of those steps which had led up to their formation. In such way the primitive metaphorical thinking changed into the mythological one" (Naydysh 2010: 217). The researcher notices that the linguistic theory of myth postulates that the metaphorical thinking cannot coexist with the abstract one, because the sensory image is destroyed by abstraction, and makes conclusion that "the linguistic theory treated myth as a result not of progress, but of degradation of the human mentality, because "the sickness of language" is "the sickness of mind" at the same 
time. Myth is not the expression of the peculiar "tension" of the primitive mind, but its weakening, lowering" (Naydysh 2010: 217).

The representatives of the linguistic theory of myth endeavored to study out what natural phenomena were so impressive for the primitive humans that they began divinizing the nature. These attempts established solar and atmospheric conceptions of myth (A. Kuhn, F. Wendorff et al.) which were directed to "search of that initial, imbued with emotions images of natural phenomena which were the basis for arising of myths. Under these conceptions the relation between myth and metaphor was proved not only by means of linguistics, but also psychologically, that is through the role of perception in the formation of sensory images and abstractions" (Naydysh 2010: 218). The researchers considered that characteristics of mythological gods were formed on the basis of visible images generated by astronomic and atmospheric phenomena which were "reflected in the human consciousness in form of imbued with emotions concepts. The result was the metaphors (which personified humans' features and were understandable for them) from which then (as a result of "the sickness of language") the mythological images were formed" (Naydysh 2010: 218).

Whereas W. Wundt, who turned the study of mythology to the tide of psychology, made a critical remark about attempts to bring mythology out of only one mental process which is conceptualization: "instead of taking into account all psychological processes [...] they give preference to conceptualization" (Wundt 1914: 39). According to W. Wundt, consciousness is a complicated active system which is formed with a number of interrelated processes (intellectual, conative, emotional), and myth is the initial form of consciousness, that is why the researcher considered that the motive force of mythogenesis is not the conceptualization, but emotions: "the essential spring of mythological mind and behavior [...] were not concepts, but affects which follow the concepts everywhere and penetrate into formation of concepts as the powerful stimulus of fantasy. The affects of fear and hope, desire and passion, love and hatred are the sources of myth spread everywhere. Certainly, they are always connected with concepts. But only they along breathe life into these concepts" (Wundt 1914: 40).

According to this view, the source of mithogenesis is not the cognitive sphere of the human consciousness, but emotional one. A. Losev notices that it is incorrect "to treat mythology as an attempt to explain or understand the nature and society by the primitive human", because "every explanation of the nature and society, even the most mythological, is already the result of cognition that differs from myth which fulfil any function with the exception of cognitive one [...] mythology is not the explanation of nature, because the mythological explanation of nature already foresees the availability of mythology, that is why the explanatory function of mythology is secondary" (Losev 1964: 457-458). However, the content of myth is determined by association of the ideas and combination of various psychic elements of the complete system of consciousness.

H. Usener, who is considered to be the representative of the linguistic theory of myth, also reclined upon the tight relation between language and myth in his researches, however, in contrast to M. Müller, he treated this relation as the entirety of the system "myth language", because he was sure that language and myth have common sources: "Ideas about spirits and gods arise not during the passive contemplation of discrete objects, but at the moments of especially active states of mind, in the periods of its tension and enervation. The language has same source", that is "intensification and concentration of the sensory experience generate both the language and myth" (Naydysh 2010: 225). Thus we can conclude that $\mathrm{H}$. Usener abandoned himself to the idea about the primary nature of the language, but affirmed that language and myth have common sources. 
4.2. The Anthropological Theory of Myth is based on the critics of the linguistic theory of myth, especially of the statements formulated by M. Müller. Thus E. Tylor is positive of that mythological anthropomorphize of nature "cannot be reduced to the simple poetical fancies or to the simple metaphor, because these ideas are based on the extensive philosophy of nature, [...] which was apprehend as quite real and serious" (Tylor 1989: 129130). The researcher argues that "the mythology of the primitive societies is based on the real and perceptible analogy, and [...] development of the verbal metaphor to myth refers to later periods of civilization". This implies that "material myth" is the initial and "verbal myth" is the secondary formation (Tylor 1989: 138). As we can see, E. Tylor makes an objection to the initial mythogenic nature of the verbal metaphor, that is linguistic metaphor, but he accentuates on the importance of the cognitive process (or cognitive mechanism) of analogy both for the modern human mind and for primitive one: "the analogy is still the main tool and at the earlier stages of culture development its influence was infinite" (Tylor 1989: 136-137). "No matter how deeply language underlies the understanding of life, but the straight comparisons of an object with another object or an action with another action are considerably deeper" (Tylor 1989: 138). The issue here is the mythogenic potential of the cognitive metaphor which is based on the analogue thinking (that is cognitive power) of the primitive human.

A. Potebnya also disagrees with M. Müller, referring to H. Spencer the researcher argues that, firstly, assumptions that "high level of human mind and its further lowering are unmotivated and contradicting the theory of evolutional development of the human mind" and, secondly, the statement that "myth is the sickness of language in an unconscious state and therefore the initial word meaning (and then the thought related to it) is considerably higher than myth" contradicts a statement of M. Müller "about the initial concreteness of language", because it would mean that at first the humans were able to think abstractly and name the abstract concepts directly, but then for no apparent reason they began depriving the words of abstractness using concrete and sensory analogies instead (Potebnya 1989: 254-256).

As J. Ortega y Gasset, A. Potebnya claims that "metaphoricity of expression, properly, arises with the human's ability to comprehend, retain the difference between the subjective source of the thought cognizing the world and its movement toward this cognition", because what we understand "just as the comparison was the truth for the humans in the period of mythological mind until they recognize only insignificant differences between the objects under comparison", and this disproves the M. Müller's thought "about forgetting of the main meanings of the words [...] as the source of myths" (Potebnya 1989: 262). A. Potebnya is speaking here about metaphor as a hidden comparison which is realized, and that is why as if it is impossible for the mythological mind which did not distinguished the subject and the object equating the object and the thought about it, however exactly the latter generates the primary mythological metaphor which disappearing caused by the realization the differences between the objects under comparison (the objects of analogy) and the thought about them indicates the forward motion of the human mind from the sensory imagery to the critical abstractness.

\subsection{Neo-Kantian Interpretation of Myth.}

E. Cassirer considers both language and myth as the symbolical forms of culture. The philosopher emphasizes tight relation between the mythological and linguistic worlds which is based, in his opinion, on the metaphorical thinking: "No matter how much myth and language differ in content, they both, as it turns out, have in common the same conceptual form. This form can be defined as the metaphorical thinking" (Cassirer 1990: 33). Linguistic and mythological metaphors have common origin: "there is the completion of the same inner process both in the sounds of language and in the primitive mythological images: both of 
them relieve the inner tension, express mental experience through the objectified forms and figures", that is their origin in rooted in "the concentration of the sensory experience" (Cassirer 1990: 36). At the same time E. Cassirer, on the one hand, speaks about metaphor "as the deliberate transfer of some notion onto other sphere, that is onto other notion", however, on the other hand, he notices that this process becomes possible when the notions are already fixed in the language, that is why "it is necessary to distinguish really "fundamental" metaphor which is the condition of creation both of the language and the mythological notions" (Cassirer 1990: 35). This "fundamental" metaphor is formed through the cognitive mechanism of analogy between various natural phenomena which was inherent in the primitive human mind and enabled to express their feelings in mythological and linguistic forms.

E. Cassirer also explains already mentioned principle "a part instead of the whole", the particular case of which, according to E. Cassirer, is the principle of analogy which is fundamental for both linguistic and mythological metaphor, because in the mythological mind "every part not only represents the whole and individual represents species or genus, but they are the same; they are not only their mediated reflections, but they directly absorb the power of the whole, its meaning and reality" (Cassirer 1990: 38), what generates metaphor as the replacement or reversion of generic and subnotions. However, this process took place unconsciously, because of psychical nature of the primitive mind.

The researcher emphasizes the mythogenic potential of the linguistic metaphor since "unnamed things do not exist in the language at all, and if they are named identically, they seem to be identical", that is why "the identity of features fixed in the word" levels other aspects of the notions and causes their disappearing, that is "the language treats identically the contents which seem to be different in respect of direct sensory perception or logical classification, thus each expression intended for one content can be transferred onto another" (Cassirer 1990: 40). Therefore, mythogenic potential of the linguistic metaphor can be realized only in the environment of mythological consciousness, which is sensory and concrete, incapable of abstract thinking.

In general, E. Cassirer's approach to the solution of the problem of the language or myth primacy is not historical, but philosophical and phenomenological, because the researcher formulates this question in the next way: "Is the metaphorical expression of language anchored in mythological state of mind, or, conversely, a state of mind can be formed and developed on the basis of language?" - and he immediately notices that this question is objectless, because "obviously, the question is not about empirical ascertainment of "earlier" or "later", but just about the ideal correlation under which the linguistic form correlates with the mythological one, about how one penetrates into another and determines its content" (Cassirer 1990: 36). Thus, E. Cassirer is positive of that linguistic and mythological forms were created simultaneously and this creation was based on the same principles.

Mythological sources of language were asserted in the works of J. Herder and F. Schelling in due time and that was also noticed by E. Cassirer. In particular, J. Herder considered that "the humans created the language ... with the sounds of alive nature which were turned into features comprehended by their powerful mind", because "the sounding of every creature was heard as its name with which the human soul engraved the image of this object connecting the thought about it and its feature". Thus, when "the thought about object was at the crossroads of the agent and its action and the sound had to designate the sounding object" then "the names arose from the verbs, but not the verbs from the names" (Herder 1959: 145-146). As we can see, the philosopher considered hearing to be the most important source of perceptions for the primitive human in the process of comprehending the reality, 
however he did not escape the problem of naming of unsounding objects. J. Herder argues that various features of the object (colour, smell, sound etc.) do not exist isolated, bur "pour together" and "the less clear the perceptions are, the more they pour into each other". Arising of the words for expressing of non-hearing perceptions was caused by the fact that "the soul seized with the stream of perceptions felt the necessity to create the word and chasing this feeling, perhaps, found the word prompted by the neighbouring perception" (Herder 1959: 150-152). Obviously, the issue here is the synaesthetic perceptions, that is "the arising of one type of perceptions under the influence of the irritant of another type of analyser" (General psychology 2011: 461).

J. Herder notices that "if all nature makes sounds, it seems to the sensory human that it lives, speaks and acts", that is why "all mythology is contained in the verbs and the names" and "transformation of the verbs into the names" is "the easiest way to the abstraction" (Herder 1959: 147). At the same time the philosopher espouses the hypothesis about the primacy of the poetic language concerning the prosaic one claiming that "the natural language of the creatures imparted with intellect was embodied in the sounds and images of the action of passions and alive creativity! Its vocabulary was the vocabulary of the soul and at the same time the mythology and fairy epopee of the actions and conversations of all the creatures! In other words, it was the poetic fancy filled with passion and interest!" (Herder 1959: 148). Thus, these arguments are based, first of all, on the emotional and sensory component of the poetic language, but do not concern to its metaphoricity. However, this thought does not contradict that the primary metaphor was sensory and directed to express feelings and emotions filling the soul of the primitive human.

In this aspect, it should be mentioned the views of F. Schelling who claims that the human mind is impossible without language, that is why the basis of language could not be laid consciously: "the deeper we penetrate into it, the more clearly we reveal that its deepness surpasses every, even the most conscious work" (Schelling 2013: 47). On F. Schelling's opinion, "language is the tarnished mythology, its abstract and formal differences keep the same things as mythology", because "every name is personification" (Schelling 2013: 48). As to mental or abstract concepts F. Schelling espouses the hypothesis about the sensory concreteness of the primary metaphor.

Nowadays cognitive linguistics operates with the term of cognitive metaphor which is more old-arisen than the linguistic metaphor, because the first one reflects the process of cognition and taking the linguistic forms of the obtained knowledge. Thus, the statement that the primitive mythological thinking was quite metaphorical is true, but this metaphoricity was not linguistic, bus sensory and imagery. That is why here we can find the answer to the question about the primary nature of the myth and the secondary one of the language.

\section{Conclusions.}

To sum up, it should be noticed that the problem of the cognitive nature of primary metaphor is related with the peculiarities of the primitive human mind which is mythological, that is intuitive, sensory and deprived of the abstractions, what determined the mechanism of the primary metaphor creation, which was not linguistic, but sensory and concrete, based on the sensory analogy between the objects and phenomena of extralingual reality and the inner mental states of human. The primitive humans did not separate themselves from nature and operate with the abstract notions, however they were overfull with various feelings requiring some expression, that is why they associated these feelings with the surrounding phenomena, what subserved production of both the mythological images and linguistic forms. Hence intuitive and sensory nature of the primary nature and also the transferring of the inner states onto surroundings. 
There were three approaches of studying the metaphoricity as a property of the primitive human mind: 1) the linguistic theory of myth by M. Müller which postulated the primacy of language concerning the myth and forming of the latter through the obliteration of the initial sense of the linguistic metaphors, and also objected the possibility of coexisting of metaphoricity and abstractness of the human mind; 2) the anthropological theory of myth which representatives supposed that, firstly, myth is deeper phenomenon than the simple obliteration of the initial sense of the linguistic metaphors, but it is based on the sensory analogies between the real objects, and, secondly, the loss of ability to operate with the abstract notions and transition to the sensory analogies contradict the theory of evolutional development of the human mind; 3) Neo-Kantian theory which advances arguments for the common sources of myth and language, and their tight interplay during the development of the human cognitive abilities.

The primary metaphor as a cognitive process and its result at the same time is based on the analogue thinking and is a product of the mythological mind. Transformation of the mythological mind started the development of the abstract thinking, and therefore the metaphorization veer. Modern people use the elements of the concrete domain to express the abstract one. The abstract thinking did not take the place of the metaphorical one, they became interdependent and creatively complemented one another, that is both linguistic and cognitive metaphors make it possible to comprehend and express novel conceptions, and the critical abstract thinking assists to escape misunderstanding of metaphor. Perspectives of the further researches are connected with the revealing of the cognitive mechanism of analogy of the primary metaphors in the poetic text.

\section{References}

Cassirer, E. (1990). Sila Metafory [The Power of Metaphor]. Teoriya metafory. obshch. red. N. D. Arutyunovoy, M. A. Zhurinskoy. M. : Progress. 33-43.

Cienki, A. (1998). Metaphoric gestures and some of their relations to verbal metaphoric expressions. Discourse and Cognition: Bridging the Gap. ed. Jean-Pierre Konig. Stanford, California: CSLI (Center for the Study of Language and Information). 189-204.

Frazer, J. (1986). Zolotaya vetv [The Golden Bough]. M.: Izd-vo politicheskoy literatury. 704.

Freeman, M. (2003). Poetry and the scope of metaphor: Toward a cognitive theory of literature. Metaphor and Metonymy at the Crossroads: A Cognitive Perspective. eds A. Barcelona. Berlin; New York: Mouton de Gruyter. 253-281.

Herder, J. G. (1959). Traktat o proiskhozhdenii yazyka [Treatise on the Origin of Language]. Izbrannye sochineniya. sost. V. M. Zhirmunskiy. M.-L.: Gosudarstvennoe izdatelstvo khudozhestvennoy literatury. 133-154.

Holyoak, K. J., Stamenkovic, D. (2018). Metaphor Comprehension: A Critical Review of Theories and Evidence. Psychological Bulletin. 144. 6. 641-671.

Jung, C. Ob arkhetipakh kollektivnogo bessoznatelnogo [Archetypes of the Collective Unconscious]. Retrieved from http://gtmarket.ru/laboratory/basis/4229/4232 210.

Kompa, N. (2017). The Myth of Embodied Metaphor. Croatian Journal of Philosophy. 17. 50. 195-

Kövecses, Z. (2010). Metaphor: A Practical Introduction. $2^{\text {nd }}$ ed. Oxford etc.: Oxford University Press. 396.

Kravtsova, Yu. V. (2011). Metaforicheskoe modelirovanie mira: poeziya i proza [Metaphorical modeling of the world: poetry and prose]. K.: Izd-vo NPU im. M. P. Dragomanova. 360.

Kuhn, A. (1859). Die Herabkunft des Feuers und des Göttertranks [The descent of the fire and the deity]. Berlin: Ferd. Dümmler's Verlagsbuchhandlung. 285.

Lakoff, G. (1993). The contemporary theory of metaphor. Metaphor and Thought. ed. A. Ortony. N. Y. : Cambridge University Press. 202-251.

Lakoff, G., Johnson, M. (1999). Philosophy in the Flesh: The Embodied Mind and Its Challenge to Western Thought. N. Y. : Basic Books. 624. 
Losev, A. F. (1964). Mifologiya (Mythology). Filosofskaya entsiklopediya. M. : Izdatelstvo "Sovetskaya entsiklopediya". 3. 457-466.

Mozheyko, M. A. (2003). Mifologiya (Mythology). Noveyshiy filosofskiy slovar. 3-e izd., ispravl. Minsk: Knizhnyy Dom. 634-638. Retrieved from http://www.gumer.info/bogoslov_Buks/ Philos/New_Dict/477.php

Müller, M. (1887). Religiya, kak predmet sravnitelnogo izucheniya [Introduction to the Science of Religion]. per. A. M. Gilevicha. Kharkov: Tipografiya Adolfa Darre. 138.

Müller, M. (2009). Lektsii po nauke o yazyke [Lectures on the Science of Language]. predisl. K. G. Krasukhina. 2-e izd., dop. M. : Knizhnyy dom "LIBROKOM". 314.

Naydysh, V. M. (2010). Mifologiya: uchebnoe posobie [Mythology: tutorial]. M. : KNORUS. 432.

Ortega y Gasset, J. (1990). Dve velikie metafory [The Two Great Metaphors]. Teoriya metafory. obshch. red. N. D. Arutyunovoy, M. A. Zhurinskoy. M. : Progress. 68-81.

Potebnya A. A. (1989). Slovo i mif [Words and Myths]. M. : Izdatelstvo "Pravda". 622.

Rudzka-Ostyn, B. (1995). Metaphor, schema, invariance: The case of verbs of answering. By Word of Mouth: Metaphor, Metonymy and Linguistic Action in a Cognitive Perspective. Amsterdam: John Benjamins. $205-243$.

Schelling, F. (2013). Filosofiya mifologii: $v 2 t$. [Philosophy of Mythology: in 2 vol.]. SPb. : Izdatelskiy dom Sankt-Peterburgskogo gosudarstvennogo universiteta. 1. Vvedenie v filosofiyu mifologii (Introduction to the Philosophy of Mythology). per. s nem. V. M. Lineykina. khkhiv +480.

Spencer, H. (1876). Osnovaniya sotsiologii: $v 2$ t. [The Principles of Sociology: in 2 vol.]. SPb. : Izd. I. I. Bilibina. 1. 496.

Timofeev, V. G., Petrov, N. V. (2010). Svoystva mifologicheskogo soznaniya [Properties of mythological conscience]. Vestnik Chuvashskogo universiteta. 4. 146-151.

Tsur, R. (1992). Toward a Theory of Cognitive Poetics. Amsterdam etc.: Elsevier Science Publ. 580.

Turner, M., Fauconnier, G. (2003). Metaphor, metonymy, and binding. Metaphor and Metonymy at the Crossroads: A Cognitive Perspective. ed. A. Barcelona. Berlin; New York: Mouton de Gruyter. 133-148.

Tylor, E. (1989). Pervobytnaya kultura [Primitive culture]. M. : Politizdat. 573.

Usener, H. (1896). Götternamen. Versuch einer Lehre von der religiösen [Gods name. Attempt of a doctrine of the religious]. Begriffsbildung. Bonn: Verlag von Friedrich Cohen. 391.

Vico, G. (1994). Osnovanie novoy nauki [The New Science]. M.-K. : "RELF-book" - "ISA". 656.

Wendorff, F. (1889). Erklärung aller mythologie aus der annahme der erringung des sprechvermögens (mit vorzüglicher berücksichtigung des griechischen und sanskritischen idioms) [Explanation of all mythology from the assumption of the power of speech (with exquisite consideration of the Greek and Sanskrit idioms)]. Berlin, Nauck. 199.

Wundt, W. (1914). Mif i religiya [Myth and Religion]. SPb. : Izdanie Brokgauz-Yefron. 427.

Zahalna psykholohiia: Pidruchnyk [General psychology: Textbook] (2011). eds O. V. Skrypchenko, L. V. Dolynska, Z. V. Ohorodniichuk ta in. K. : Karavela. 464.

\section{Бібліографічний опис:}

Бородійчук, Н.В. (2018). Когнітивний механізм аналогії та його роль у процесах творення первісної метафори. Науковий часопис Національного педагогічного університету імені М. П. Арагоманова. Серія 9 Сучасні тенденцій розвитку мов. К. Вип. 17. С. 5-18. DOI: https://doi.org/10.31392/NPU-nc.series9.2018.17.01

\section{Анотація}

У статті розглядається когнітивна сутність метафори, яка формувалась у середовищі міфологічної свідомості первісної людини. Зроблено припущення, що такі основні властивості міфологічного мислення, як чуттєва конкретність та нездатність до формування абстрактних понять зумовили і характер первісної метафори, яка утворювалась шляхом когнітивного механізму аналогії між предметами й явищами довкілля та внутрішніми душевними станами людини і була не мовною метафорою, а чуттєво-конкретною. Установлено, що напрям прочесу метафоризаиії у свідомості первісної людини був оберненим до сучасного, адже сучасна людська свідомість 
використовуе більш доступні для сприйняття конкретні поняття для вираження абстрактних понять, а первісна людина, яка уявляла себе частиною природи, розуміла свій внутрішній світ як зовнішній, проектувала внутрішні стани, які нині усвідомлюються як абстрактні, на явища природи, що сприймаються органами чуття. Аргументовано, що формування абстрактно-критичного мислення у людини пов'язане із розвитком когнітивних здібностей людини, що зумовило інший напрям прочесу метафоризаиії, а також перехід від міфологічної свідомості до мовної. Проаналізовано три підходи учених до вирішення питання про взаємозв'язок міфу та мови, для яких вагомим аргументом була метафоричність як мислення, так і мови: 1) лінгвістична теорія міфу М. Мюллера, відповідно до якої втрата усвідомлення первісного значення мовної метафори породила міф; 2) міфологічна теорія, що трунтується не на мовній метафорі, а на конкретно-чуттєвій аналогії реальних предметів та відчуттів людини (Е. Тайлор, О. Потебня та ін.); 3) неокантіанська теорія Е. Кассірера, яка постулює паралельний розвиток мови і міфу, що мають спільні витоки. Доведено, що метафоричність притаманна мисленню людини будь-якої епохи, адже мовна метафора утворюється на основі когнітивної, тобто саме остання дозволяє осягнути світ та себе в ньому і виразити набуті знання в мовній формі. При цьому метафоричність та абстрактність мислення є гармонійними прочесами, щяо забезпечують продуктивне пізнання світу людиною та творчу переробку його результатів шляхом фіксаиії у мовній формі.

Ключові слова: первісна метафора, міфологічна свідомість, когнітивний механізм аналогії, мовна метафора, когнітивна метафора. 